\title{
Evaluation of the Relationship between Type II Diabetes Mellitus and the Prevalence of Apical Periodontitis in Root-Filled Teeth Using Cone Beam Computed Tomography: An Observational Cross-Sectional Study
}

\author{
Selen Nihal Sisli \\ Department of Endodontics, Faculty of Dentistry, Baskent University, Ankara, Turkey
}

\section{Significance of the Study}

- A possible association between type II diabetes mellitus and apical periodontitis was evaluated in this study using cone beam computed tomographic images of adequately root-filled and restored teeth. A greater prevalence of apical periodontitis and severe bone destruction was observed in patients with diabetes mellitus compared with nondiabetic patients.

\section{Keywords}

Periapical periodontitis · Diabetes mellitus · Cone beam computed tomography

\footnotetext{
Abstract

Objective: This study aimed to investigate the prevalence of apical periodontitis (AP) in patients with type Il diabetes mellitus (DM) with either optimal glycemic control (OGC) or poor glycemic control (PGC) compared with nondiabetics using cone beam computed tomography $(C B C T)$. Subjects and Methods: The periapical status of 75 teeth with adequate root canal treatment performed at least 1 year ago that could be visualized in the field of view of CBCT images of 43 DM patients ( 29 females, 14 males) was compared with a control group consisting of 162 teeth of 86 nondiabetics ( 56 females, 30 males). In addition, the DM group was divided into sub-
}

groups according to the patients' mean glycated hemoglobin level as either having OGC or PGC. The periapical status of the teeth was evaluated using the CBCT periapical index (CBCTPAI), and AP was diagnosed as a CBCTPAI $\geq 1 . X^{2}$, Fisher's exact test, and independent-samples $t$ tests were used for the statistical analysis, and $p<0.05$ was considered significant. Results: Significant differences between the DM group and the control group were observed $(p<0.05)$ in terms of AP (the frequencies of both CBCTPAI $\geq 1$ and CBCTPAI $\geq 3$ ) and the frequency of cardiovascular disease, while there were no significant differences between the DM subgroups ( $p>0.05)$. Conclusion: The prevalence of AP and severe bone destruction in periapical tissues was significantly higher in the DM patients compared with the nondiabetic patients.

C 2019 The Author(s)

Published by S. Karger AG, Basel

\begin{tabular}{|c|c|c|}
\hline KARGER & $\begin{array}{l}\text { (๑) } 2019 \text { The Author(s) } \\
\text { Published by S. Karger AG, Basel }\end{array}$ & $\begin{array}{l}\text { Karger } \\
\text { Open access }\end{array}$ \\
\hline $\begin{array}{l}\text { E-Mail } \\
\text { www.ka }\end{array}$ & $\begin{array}{l}\text { This is an Open Access article licens } \\
\text { Attribution-NonCommercial- } 4.0 \text { In } \\
\text { (http://wwww.karger.com/Services/O } \\
\text { the online version of the article only. } \\
\text { mercial purposes requires written pe }\end{array}$ & $\begin{array}{l}\text { the Creative Commons } \\
\text { al License (CC BY-NC) } \\
\text { sLLicense), applicable to } \\
\text { nd distribution for com- } \\
\text { n. }\end{array}$ \\
\hline
\end{tabular}

Selen Nihal Sisli

Baskent University, Adana Dr. Turgut Noyan Healthcare Center Gulhatmi Street No: 37/A Yuregir TR-01230 Adana (Turkey)

E-Mail selennihalsarac@gmail.com 


\section{Introduction}

Polymicrobic agents originating from the necrotic dental pulp can cause apical periodontitis (AP), which is characterized by an inflammatory response and bone destruction in periapical tissues $[1,2]$. Bone destruction from AP can be identified radiographically as localized radiolucent destruction in the corresponding tooth root apex of the adjacent bone tissue [3]. Ideally, endodontic treatment should clean, disinfect, and fill all the root canals hermetically, aiming to cure the AP. However, inadequately aseptic environments, procedural errors, and systemic disease can disrupt the recovery mechanism of an endodontic treatment [4] and cause persistent AP.

A systemic disease possibly associated with AP that has been investigated is diabetes mellitus (DM), which results from the absence (type I DM) or deficiency (type II DM) of insulin [5]. DM is a chronic disease that leads to specific complications associated with hyperglycemia and is associated with delayed healing, a decrease in cytokine production, and a diminished tissue repair capacity, including neutrophil chemotaxis [6]. The level of glycated hemoglobin $\left(\mathrm{HbA}_{1 \mathrm{c}}\right)$ has been accepted as the most important reference for controlling mean glycemia and predicting the risk of the development of DM complications [7]. According to the American Association of Clinical Endocrinologists, an $\mathrm{HbA}_{1 \mathrm{c}}$ level of $\leq 6.5 \%$ is considered the goal for optimal glycemic control in diabetic patients [8].

Investigations of the hypothesis that $\mathrm{DM}$ is associated with a higher incidence of AP, using both animal [9-12] and human $[5,6,13-15]$ models, have yielded inconclusive results. All previous human studies [5, 6, 13-15] have used panoramic or periapical radiographs in their methodology, although the limitations of conventional radiographic methods (i.e., the 2D nature of the image, anatomical noise, geometric distortion, and possible dismissal of periapical lesions within cancellous bone) are well established [16, 17]. Recently, cone beam computed tomography (CBCT) imaging has gained popularity in epidemiological studies because its 3D nature allows for the detection of AP before it can be recognized radiographically $[18,19]$. In addition to the reports of CBCT imaging results in higher detection rates of $\mathrm{AP}, \mathrm{CBCT}$ scanning produces findings closer to histologic evaluations [2022 ]. Therefore, by having superior validity and reliability compared with radiographs, CBCT minimizes false diagnoses. Despite these outstanding features, the radiation dose is significantly higher compared with conventional radiographic techniques [23]; therefore, the American
Association of Endodontists and the American Academy of Oral and Maxillofacial Radiology recommend that the application of CBCT with limited field of view (FOV) can be the method of choice when the third dimension is needed [23]. Existing CBCT images can be analyzed to obtain additional information from incidental findings that may be discovered within the FOV [24, 25].

This cross-sectional study aimed to compare the prevalence of AP in root-filled teeth in type II diabetic patients with optimal glycemic control (OGC) and poor glycemic control (PGC) with that of nondiabetic patients from a Turkish subpopulation using CBCT evaluations.

\section{Subjects and Methods}

\section{Study Design and Data Source}

The records of DM patients who had been followed up in the Endocrine Polyclinic and also attended the Dental Polyclinic of the Adana Baskent University between December 2014 and December 2017 were scanned for this study. Type II DM patients with a history of immunosuppressive medication or chemotherapy and a lack of follow-up information were excluded, and those who coincidentally had CBCT scans performed for any diagnostic reasons were listed.

\section{Inclusion Criteria}

Patients with at least one tooth with an adequate root canal treatment and coronal restoration within the FOV of an existing CBCT were selected. However, after careful examination of the anamneses, if the root canal treatment of a selected tooth was found to have been performed less than 1 year ago, the subject was excluded. Additionally, root-filled teeth without permanent restoration were also excluded. Ultimately, 75 teeth of $43 \mathrm{DM}$ patients with adequate root canal treatment were included in the study.

Information about the most recent $\mathrm{HbA}_{1 \mathrm{c}}$ levels, the presence of cardiovascular disease (CVD), and the age and gender of the patients (29 females, 14 males; mean age $56.40 \pm 10.30$ years) were obtained from the hospital's medical database. Adequate glycemic control was defined according to the American Association of Clinical Endocrinologists as an $\mathrm{HbA}_{1 \mathrm{c}}$ level $\leq 6.5 \%$ [8]. Based on $\mathrm{HbA}_{1 \mathrm{c}}$ levels, the DM patients were divided into two subgroups: those with an $\mathrm{HbA}_{1 \mathrm{c}}$ level $\leq 6.5 \%$ were placed in the OGC group and those with an $\mathrm{HbA}_{1 \mathrm{c}}$ level $>6.5 \%$ were placed in the PGC group. Thirty DM patients (53 teeth in total) were placed in the OGC group, while 13 patients (22 teeth in total) were placed in the PGC group. As a control group, 162 teeth with adequate root canal treatment of 86 patients whose age and gender distribution was compatible with the DM group (56 females, 30 males; mean age $56.28 \pm 10.07$ years) were selected from the CBCT patient records. The inclusion criteria for the control group were the same as those for the DM group.

\section{CBCT Examination and Evaluation}

All of the CBCT scans were performed by two trained technicians using a Pax-i3D apparatus (Vatech, Hwaseong, South Korea) with the manufacturer's recommended exposure conditions (24 s, $90 \mathrm{kVp}$, and $5.7 \mathrm{~mA}$ ) with a voxel size of $0.200 \mathrm{~mm}$ at 4 different 
Table 1. Cone beam computed tomography periapical index (CBCTPAI) scores defined by Estrela et al. [27]

\begin{tabular}{ll}
\hline Score & $\begin{array}{l}\text { Quantitative bone alterations in mineral struc- } \\
\text { tures }\end{array}$ \\
\hline 0 & Intact periapical bone structures \\
1 & Diameter of periapical radiolucency $>0.5-1 \mathrm{~mm}$ \\
2 & Diameter of periapical radiolucency $>1-2 \mathrm{~mm}$ \\
3 & Diameter of periapical radiolucency $>2-4 \mathrm{~mm}$ \\
4 & Diameter of periapical radiolucency $>4-8 \mathrm{~mm}$ \\
5 & Diameter of periapical radiolucency $>8 \mathrm{~mm}$ \\
\hline Score, $n+\mathrm{E}^{*}$ & Expansion of periapical cortical bone \\
\hline Score, $n+\mathrm{D}^{*}$ & Destruction of periapical cortical bone
\end{tabular}

* The variables E (expansion of cortical bone) and D (destruction of cortical bone) were added to each score if either of these conditions was detected in the CBCT analysis.

FOVs: $50 \times 50,80 \times 50,80 \times 80$, and $120 \times 90 \mathrm{~mm}$. EasyDent V4 Viewer (Version 4.1.4.5.) software was used for the reconstruction of the images. The quality of the root canal fillings was examined according to a modified form of the criteria described by De Moor et al. [26]. An adequate root canal filling was defined as a complete filling ending at least $1-2 \mathrm{~mm}$ from the apex with no voids. An inadequate filling was defined as a poorly condensed filling with an over- or under-root filling length. For teeth with multiple canals, the quality of the root canal filling was ranked according to the root canal with the worst quality.

The periapical status of the teeth was independently evaluated by two experienced endodontists that had been previously calibrated in using the cone beam computed tomography periapical index (CBCTPAI) [27]. This index uses a 6-point scoring system from 0 to 5, with 2 variables describing the expansion (E) and destruction (D) of cortical bone (Table 1). The CBCTPAI score was determined by the largest extension of the lesion. A CBCTPAI score $\geq 1$ was considered to be a sign of AP. In multirooted teeth, the worst CBCTPAI score of all the roots was used. The kappa coefficient was used at the end of the evaluation to analyze the agreement between the evaluators of the presence and/or absence of AP $(\mathrm{k}=0.89)$. Cases in which the evaluators disagreed were resolved by joint discussion until consensus was achieved.

\section{Statistical Analysis}

The minimum sample size for each group of 70 root-filled and restored teeth was estimated according to $\alpha=0.05$ and a power of $80 \%$ using http://powerandsamplesize.com/Calculators/Compare-2-Proportions/2-Sample-Equality. The SPSS (Version 23.0) package program was used for the statistical analysis of the data. Categorical measurements were summarized using numbers and percentages, whereas means and standard deviations (median and minimum-maximum values where necessary) were used for continuous measurements. $\chi^{2}$ or Fisher's exact tests were used for the comparisons of categorical variables. Independent-samples $t$ tests were used for the comparisons of continuous measurements between groups. Values of $p<0.05$ were considered significant.
Table 2. Distribution of CBCTPAI scores of teeth in DM and control groups

\begin{tabular}{|c|c|c|c|c|c|}
\hline & & & \multicolumn{2}{|l|}{ Groups } & \multirow[t]{2}{*}{ Total } \\
\hline & & & control & $\mathrm{DM}$ & \\
\hline \multirow[t]{14}{*}{ СВСТРAI } & \multirow[t]{2}{*}{0} & Count of teeth & 116 & 47 & 163 \\
\hline & & $\%$ within group & 71.6 & 62.7 & 68.8 \\
\hline & \multirow[t]{2}{*}{1} & Count of teeth & 15 & 4 & 19 \\
\hline & & $\%$ within group & 9.3 & 5.3 & 8.0 \\
\hline & \multirow[t]{2}{*}{2} & Count of teeth & 20 & 8 & 28 \\
\hline & & $\%$ within group & 12.3 & 10.7 & 11.8 \\
\hline & \multirow[t]{2}{*}{3} & Count of teeth & 4 & 4 & 8 \\
\hline & & $\%$ within group & 2.5 & 5.3 & 3.4 \\
\hline & \multirow[t]{2}{*}{4} & Count of teeth & 3 & 3 & 6 \\
\hline & & $\%$ within group & 1.9 & 4.0 & 2.5 \\
\hline & \multirow[t]{2}{*}{5} & Count of teeth & 0 & 2 & 2 \\
\hline & & $\%$ within group & 0.0 & 2.7 & 0.8 \\
\hline & \multirow[t]{2}{*}{$5+\mathrm{D}$} & Count of teeth & 4 & 7 & 11 \\
\hline & & $\%$ within group & 2.5 & 9.3 & 4.6 \\
\hline \multirow{2}{*}{\multicolumn{2}{|c|}{ Total }} & Count of teeth & 162 & 75 & 237 \\
\hline & & $\%$ within group & 100.0 & 100.0 & 100.0 \\
\hline
\end{tabular}

CBCTPAI, cone beam computed tomography periapical index; $\mathrm{D}$, destruction of cortical bone.

Table 3. Distribution of CBCTPAI scores of teeth in OGC and PGC groups

\begin{tabular}{|c|c|c|c|c|c|}
\hline & & & \multicolumn{2}{|l|}{$\mathrm{DM}$} & \multirow[t]{2}{*}{ Total } \\
\hline & & & OGC & PGC & \\
\hline \multirow{14}{*}{$\begin{array}{l}\text { CBCTPAI } \\
\text { score }\end{array}$} & \multirow[t]{2}{*}{0} & Count of teeth & 33 & 14 & 47 \\
\hline & & $\%$ within group & 62.3 & 63.6 & 62.7 \\
\hline & \multirow[t]{2}{*}{1} & Count of teeth & 3 & 1 & 4 \\
\hline & & $\%$ within group & 5.7 & 4.5 & 5.3 \\
\hline & \multirow[t]{2}{*}{2} & Count of teeth & 5 & 3 & 8 \\
\hline & & $\%$ within group & 9.4 & 13.6 & 10.7 \\
\hline & \multirow[t]{2}{*}{3} & Count of teeth & 4 & 0 & 4 \\
\hline & & $\%$ within group & 7.5 & 0.0 & 5.3 \\
\hline & \multirow[t]{2}{*}{4} & Count of teeth & 1 & 2 & 3 \\
\hline & & $\%$ within group & 1.9 & 9.1 & 4.0 \\
\hline & \multirow[t]{2}{*}{5} & Count of teeth & 2 & 0 & 2 \\
\hline & & $\%$ within group & 3.8 & 0.0 & 2.7 \\
\hline & \multirow[t]{2}{*}{$5+\mathrm{D}$} & Count of teeth & 5 & 2 & 7 \\
\hline & & $\%$ within group & 9.4 & 9.1 & 9.3 \\
\hline \multirow{2}{*}{\multicolumn{2}{|c|}{ Total }} & Count of teeth & 53 & 22 & 75 \\
\hline & & $\%$ within group & 100.0 & 100.0 & 100.0 \\
\hline
\end{tabular}

CBCTPAI, cone beam computed tomography periapical index; D, destruction of cortical bone; OGC, optimal glycemic control; PGC, poor glycemic control. 
Table 4. Gender distribution and frequencies of cardiovascular disease (CVD) in DM subgroups

\begin{tabular}{|c|c|c|c|c|c|}
\hline & & & \multicolumn{2}{|l|}{$\mathrm{DM}$} & \multirow[t]{2}{*}{ Total } \\
\hline & & & $\begin{array}{l}\text { OGC } \\
\text { (mean age } \\
55.53 \text { years) }\end{array}$ & $\begin{array}{l}\text { PGC } \\
\text { (mean age } \\
59.33 \text { years) }\end{array}$ & \\
\hline \multirow[t]{2}{*}{ Gender } & female & Count of patients & $\begin{array}{l}22 \\
73.3 \%\end{array}$ & $\begin{array}{c}7 \\
53.8 \%\end{array}$ & $\begin{array}{l}29 \\
67.4 \%\end{array}$ \\
\hline & male & Count of patients & $\begin{array}{c}8 \\
26.7 \%\end{array}$ & $\begin{array}{c}6 \\
46.2 \%\end{array}$ & $\begin{array}{l}14 \\
32.6 \%\end{array}$ \\
\hline Total & & Count of patients & $\begin{array}{c}30 \\
100.0 \%\end{array}$ & $\begin{array}{c}13 \\
100.0 \%\end{array}$ & $\begin{array}{c}43 \\
100.0 \%\end{array}$ \\
\hline \multirow[t]{2}{*}{ Presence of CVD } & absent & Count & $\begin{array}{l}15 \\
50.0 \%\end{array}$ & $\begin{array}{c}5 \\
38.5 \% \\
\end{array}$ & $\begin{array}{l}20 \\
46.5 \%\end{array}$ \\
\hline & present & Count & $\begin{array}{l}15 \\
50.0 \%\end{array}$ & $\begin{array}{l}8 \\
61.5 \%\end{array}$ & $\begin{array}{l}23 \\
53.5 \%\end{array}$ \\
\hline Total & & Count & $\begin{array}{c}30 \\
100.0 \%\end{array}$ & $\begin{array}{c}13 \\
100.0 \%\end{array}$ & $\begin{array}{c}43 \\
100.0 \%\end{array}$ \\
\hline
\end{tabular}

\section{Results}

CBCTPAI scores for the DM group and the control group are presented in Table 2. The frequency of AP was $37.3 \%$ for the DM group and $28.4 \%$ for the control group, and this difference was statistically significant $(p<0.05)$. The frequency of CBCTPAI score $\geq 3$ in the DM group was $21.3 \%$, while it was $6.79 \%$ in the control group, and this difference was also statistically significant $(p<0.05)$.

There was no significant difference between the DM group and the control group in terms of age, gender, and type of teeth evaluated (teeth with single root canals vs. teeth with multiple root canals). The frequencies of teeth with single root canals were 73.4 and $71.7 \%$ for the DM group and the control group, respectively. The frequencies of teeth with multiple root canals were 26.6 and $28.3 \%$ for the DM group and the control group, respectively.

In the DM group, 23 patients (53.5\% of the DM group) had CVD, while 16 patients in the control group (18.6\%) had CVD. This difference was found to be statistically significant $(p<0.05)$.

The CBCTPAI scores for the DM subgroups are presented in Table 3. The gender distribution and frequencies of CVD are presented in Table 4. No significant difference was found in either the frequency of AP and CVD or in the distribution of gender and age $(p>0.05)$.

\section{Discussion}

According to the results of the present study, the prevalence of AP was significantly higher in the DM patients compared with the nondiabetics. This result can be interpreted as DM adversely affecting or delaying the healing process of root canal treatments because they were performed at least 1 year previously. Since the preoperative radiologic and clinical evaluation of the treated teeth were absent, it was impossible to discriminate still-healing cases, which is the main limitation of this study. This limitation arose because the effective CBCT radiation dose is higher than that for conventional radiography, and the nature of cross-sectional study design. According to the current guidelines, $\mathrm{CBCT}$ cannot be used preoperatively when performing an ordinary root canal treatment [23]. Therefore, study subjects were coincidently visualized within the FOV of recorded CBCT images that had already been taken for any diagnostic reason. Moreover, in such a cross-sectional study design, data is collected at one point in time to state disease prevalence and associate the disease to pathogenic factors. However, these data do not capture all the information about how the root canal treatments were performed, and it is not possible to control all the factors affecting the healing process or the outcome [25]. By including only the teeth with adequate root canal fillings and restorations that were performed at least 1 year earlier and 
choosing control subjects who were age- and sex-matched to the DM group, such confounding variables were intended to be reduced.

As shown in Table 1 , CBCTPAI scores $<3$ revealed minimal bone destruction of about $2 \mathrm{~mm}$, so the frequency of a CBCTPAI score $\geq 3$ was also statistically evaluated. Consequently, as well as the frequency of a CBCTPAI score $\geq 1$, a CBCTPAI score $\geq 3$ was also significantly higher in the DM group, which indicates that severe bone destruction was significantly more frequent in the DM subjects with AP.

Similar to the findings of the present study, a recent meta-analysis [5] reported a significant association between DM and AP in endodontically treated teeth. Additionally, the findings of Arya et al. [13] from a prospective study design with a 1-year follow-up period were in accordance with the present study. They observed significantly less periapical healing in the DM group (43\%) compared with the control group (80\%). However, in a systematic review, Aminoshariae et al. [14] stated that it is impossible to infer a significant relationship between DM and endodontic outcome based on the previous inconclusive findings.

The current literature indicates that the relationship between DM and endodontic diseases is a paradox. The negative effect of DM on tissue healing and the mechanism of bone turnover is well known and supported by animal studies which show that DM induces periapical lesions [9] and has an adverse effect on vital pulp therapy [10]. On the other hand, AP is not an entirely localized periradicular problem; the cell membranes of the anaerobic gram-negative bacteria that cause AP stimulate the release of proinflammatory cytokines into the systemic circulation, thus increasing the systemic inflammatory status [28]. In an animal model, Cintra et al. [11] showed that both endodontic and periodontal infections may increase the levels of $\mathrm{HbA}_{1 \mathrm{c}}$ in both diabetic and nondiabetic rats. In addition, Astolphi et al. [12] found that the presence of a periapical lesion can have detrimental effects on insulin signaling and cause insulin resistance. In a cross-sectional clinical study that investigated the possible association between $\mathrm{HbA}_{1 \mathrm{c}} \mathrm{lev}$ els and the prevalence of AP [15], worse periapical status was found to be significantly correlated with $\mathrm{HbA}_{1 \mathrm{c}}$ levels $\geq 6.5 \%$ in type II DM patients. However, the prevalence of AP in root-filled teeth was found to be similar in both $\mathrm{HbA}_{1 \mathrm{c}}$ groups, as was reported in the present study (Table 3 ).

As 3D images were evaluated in the present study, the CBCTPAI defined by Estrela et al. [27] was preferred over
Ørstavik's index [29], which has previously been successfully used in the evaluation of 2D images. CBCTPAI offers an accurate diagnosis through the analysis of lesions in 3D high-resolution images, with CT slices obtained in mesiodistal, buccopalatal, and diagonal directions.

In the present study, the prevalence of CVD was significantly higher in the DM group. Since type II DM is related to clustered risk factors for CVD, and amongst DM patients a prevalence of $75-85 \%$ for hypertension, $70-80 \%$ for elevated LDL, and $60-70 \%$ for obesity has been reported [30], this result agrees with a well-established association between CVD and DM.

\section{Conclusion}

Within the limitations of this cross-sectional study, a significant association was observed between DM and a higher prevalence of AP in root-filled teeth and CVD. Further clinical and prospective epidemiologic investigations are needed to clarify this issue.

\section{Acknowledgment}

This study was approved and supported by Baskent University.

\section{Statement of Ethics}

The protocol for this cross-sectional study was approved by the Medical Ethics Committee of Baskent University (Project No: D-KA16/15).

\section{Disclosure Statement}

There are no conflicts of interest to declare.

\begin{tabular}{|c|c|}
\hline References & $\begin{array}{l}1 \text { Graves DT, Oates T, Garlet GP: Review of os- } \\
\text { teoimmunology and the host response in end- } \\
\text { odontic and periodontal lesions. J Oral Mi- } \\
\text { crobiol. } 2011 \text { Jan 17;3. } \\
2 \text { Siqueira JF Jr, Rôças IN. Present status and } \\
\text { future directions in endodontic microbiolo- } \\
\text { gy. Endod Topics. 2014;30(1):3-22. } \\
3 \text { Bender IB, Seltzer S. Roentgenographic and } \\
\text { direct observation of experimental lesions in } \\
\text { bone: I. 1961. J Endod. } 2003 \text { Nov;29(11): } \\
\text { 702-6. } \\
4 \text { Nair PN. On the causes of persistent apical } \\
\text { periodontitis: a review. Int Endod J.2006 Apr; } \\
\text { 39(4):249-81. }\end{array}$ \\
\hline
\end{tabular}

Med Princ Pract 2019;28:533-538 537 
5 Segura-Egea JJ, Martín-González J, Cabanillas-Balsera D, Fouad AF, Velasco-Ortega E, López-López J. Association between diabetes and the prevalence of radiolucent periapical lesions in root-filled teeth: systematic review and meta-analysis. Clin Oral Investig. 2016 Jul;20(6):1133-41.

6 Delamaire M, Maugendre D, Moreno M, Le Goff MC, Allannic H, Genetet B. Impaired leucocyte functions in diabetic patients. Diabet Med. 1997 Jan;14(1):29-34.

7 Expert Committee on the Diagnosis and Classification of Diabetes Mellitus. Report of the expert committee on the diagnosis and classification of diabetes mellitus. Diabetes Care. 2000 Jan;23 Suppl 1:S4-19.

8 Gionfriddo MR, McCoy RG, Lipska KJ. The 2013 American Association of Clinical Endocrinologists' diabetes mellitus management recommendations: improvements needed. JAMA Intern Med. 2014 Feb;174(2):179-80.

9 Iwama A, Nishigaki N, Nakamura K, Imaizumi I, Shibata N, Yamasaki M, et al. The effect of high sugar intake on the development of periradicular lesions in rats with type 2 diabetes. J Dent Res. 2003 Apr;82(4):322-5.

10 Garber SE, Shabahang S, Escher AP, Torabinejad $M$. The effect of hyperglycemia on pulpal healing in rats. J Endod. 2009 Jan;35(1): 60-2.

11 Cintra LT, Samuel RO, Facundo AC, Prieto AK, Sumida DH, Bomfim SR, et al. Relationships between oral infections and blood glucose concentrations or HbAlc levels in normal and diabetic rats. Int Endod J. 2014 Mar; 47(3):228-37.

12 Astolphi RD, Curbete MM, Colombo $\mathrm{NH}$, Shirakashi DJ, Chiba FY, Prieto AK, et al. Periapical lesions decrease insulin signal and cause insulin resistance. J Endod. 2013 May; 39(5):648-52.

13 Arya S, Duhan J, Tewari S, Sangwan P, Ghalaut V, Aggarwal S. Healing of Apical Periodontitis after Nonsurgical Treatment in $\mathrm{Pa}$ tients with Type 2 Diabetes. J Endod. 2017 Oct;43(10):1623-7.
14 Aminoshariae A, Kulild JC, Mickel A, Fouad AF. Association between Systemic Diseases and Endodontic Outcome: A Systematic Review. J Endod. 2017 Apr;43(4):514-9.

15 Sánchez-Domínguez B, López-López J, JanéSalas E, Castellanos-Cosano L, Velasco-Ortega E, Segura-Egea JJ. Glycated hemoglobin levels and prevalence of apical periodontitis in type 2 diabetic patients. J Endod. 2015 May; 41(5):601-6.

16 Patel S, Durack C, Abella F, Shemesh H, Roig M, Lemberg K. Cone beam computed tomography in Endodontics - a review. Int Endod J. 2015 Jan;48(1):3-15.

17 Estrela C, Bueno MR, Leles CR, Azevedo B, Azevedo JR. Accuracy of cone beam computed tomography and panoramic and periapical radiography for detection of apical periodontitis. J Endod. 2008 Mar;34(3):273-9.

18 Karabucak B, Bunes A, Chehoud C, Kohli MR, Setzer F. Prevalence of apical periodontitis in endodontically treated premolars and molars with untreated canal: A cone-beam computed tomography study. J Endod. 2016 Apr;42(4):538-41.

19 Nur BG, Ok E, Altunsoy M, Ağlarci OS, Çolak M, Güngör E. Evaluation of technical quality and periapical health of root-filled teeth by using cone-beam CT. J Appl Oral Sci. 2014 Nov-Dec;22(6):502-8.

20 Uraba S, Ebihara A, Komatsu K, Ohbayashi N, Okiji T. Ability of Cone-beam Computed Tomography to Detect Periapical Lesions That Were Not Detected by Periapical Radiography: A Retrospective Assessment According to Tooth Group. J Endod. 2016 Aug; 42(8):1186-90.

21 de Paula-Silva FW, Wu MK, Leonardo MR da Silva LA, Wesselink PR. Accuracy of periapical radiography and cone-beam computed tomography scans in diagnosing apical periodontitis using histopathological findings as a gold standard. J Endod. 2009 Jul;35(7):100912.
22 Kanagasingam S, Lim CX, Yong CP, Mannocci F, Patel S. Diagnostic accuracy of periapical radiography and cone beam computed tomography in detecting apical periodontitis using histopathological findings as a reference standard. Int Endod J. 2017 May;50(5): 417-26.

23 American Association of Endodontists. American Academy of Oral and Maxillofacial Radiology: AAE and AAOMR joint position statement use of cone beam computed tomography in endodontics 2015 update. J Endod. 2015;41:1393-6.

24 Oser DG, Henson BR, Shiang EY, Finkelman $\mathrm{MD}$, Amato RB. Incidental Findings in Small Field of View Cone-beam Computed Tomography Scans. J Endod. 2017 Jun;43(6):901-4.

25 Gambarini G, Piasecki L, Miccoli G, Gaimari G, Nardo DD, Testarelli L. Cone-beam computed tomography in the assessment of periapical lesions in endodontically treated teeth [Erratum in: Eur J Dent 2018;12] [2]. Eur J Dent. 2018 Jan-Mar;12(1):136-43.

26 De Moor RJ, Hommez GM, De Boever JG, Delmé KI, Martens GE. Periapical health related to the quality of root canal treatment in a Belgian population. Int Endod J. 2000 Mar; 33(2):113-20.

27 Estrela C, Bueno MR, Azevedo BC, Azevedo JR, Pécora JD. A new periapical index based on cone beam computed tomography. J Endod. 2008 Nov;34(11):1325-31.

28 Henderson B, Wilson M. Cytokine induction by bacteria: beyond lipopolysaccharide. Cytokine. 1996 Apr;8(4):269-82.

29 Ørstavik D, Kerekes K, Eriksen HM. The periapical index: a scoring system for radiographic assessment of apical periodontitis. Endod Dent Traumatol. 1986 Feb;2(1):20-34.

30 Preis SR, Pencina MJ, Hwang SJ, D’Agostino RB Sr, Savage PJ, Levy D, et al. Trends in cardiovascular disease risk factors in individuals with and without diabetes mellitus in the Framingham Heart Study. Circulation. 2009 Jul;120(3):212-20. 